J. Product. \& Dev., 25(2): 169-194(2020)

\title{
EFFECT OF GIBBERELLIC ACID AND ROYAL JELLY INJECTION ON SOME PRODUCTIVE, REPRODUCTIVE AND PHYSIOLOGICAL TRAITS IN MATROUH CHICKENS STRAIN DURING SUMMER SEASON.
}

\author{
W. Ezzat ${ }^{1}$; A.M. Rizk' ${ }^{1}$ Hanan S. Mohamed ${ }^{1}$ and I. A. Fathey ${ }^{2}$ \\ 1.Poult. Breed. Res. Dep., Anim. Prod. Res. Inst., Agric. Res. Centre, Min. of \\ Agric., Giza, Egypt. \\ 2.Poult. Nutr. Res. Dep., Anim. Prod. Res. Inst., Agric. Res. Centre, Min. of \\ Agric., Giza, Egypt. *Corresponding Author: dr.waheed_ezzat@yahoo.com
}

\section{ABSTRACT:}

A total of 168 laying hens and 21 cocks of Matrouh local strain at 24 weeks of age (At $43.93 \%$ egg production)was used in a completely randomized design among seven treatment groups with three replicates per treatment group ( 8 hens and 1 cock per replicate).Birds are biweekly injected, up to 36 weeks of age (12 weeks). The $1^{\text {st }}$ treatment group of birds were injected with saline solution $0.9 \%$ only and served as control, The birds in $2^{\text {nd }}$ and $3^{\text {rd }}$ treatment groups, were injected subcutaneously with 100 and $200 \mu \mathrm{g}$ Gibberellic acid (GA3)/kg body weight $(B W)$, respectively. The $4^{\text {th }}$ and $5^{\text {th }}$ treatment groups were injected with50 and $100 \mu \mathrm{g}$ Royal Jelly $(\mathrm{RJ}) / \mathrm{kg} \mathrm{BW}$, respectively. The $6^{\text {th }}$ treatment group was injected subcutaneously with $50 \mu \mathrm{g}$ GA3 plus $25 \mu \mathrm{g}$ $R J / k g B W$. The $7^{\text {th }}$ treatment group was injected subcutaneously with $100 \mu \mathrm{g} \mathrm{GA3}$ plus $50 \mu \mathrm{g} R / \mathrm{kg} B W$. The same 7 treatment groups were used also, on 21 cocks in individual batteries to take semen quality.

The obtained results revealed that, Injection with $100,200 \mu \mathrm{g}$ GA3 or50 , $100 \mu \mathrm{g} \mathrm{RJ} / \mathrm{kg} B W$ of Matrouh chicks improved significantly $(P<0.05$ and $P<0.01)$ body weight changes $(B W C)$,fertility eggs \%, hatchability/total eggs \% and chicks hatch weight (g), sperm-cell concentration $\left(X 10^{9} / \mathrm{ml}\right)$ and sperm motility (\%), while significantly $(P<0.05)$ decreased each of dead spermatozoa (\%), sperm abnormalities $(\%)$, and acrosomal damage (\%) as compared with the control group. Layers injected by $100,200 \mu \mathrm{gGA3} / \mathrm{kg}$ body weight showed significantly $(P \leq 0.05$ and $P \leq 0$. 01) improved feed conversion ratio (FCR), egg production (EP)\% and egg mass (EM) compared with those the groups 
$50,100 \mu \mathrm{g} \mathrm{RJ} / \mathrm{kg} \mathrm{BW}$ and control groups through the whole of the experimental period. Injection with $50,100 \mu \mathrm{g}$ of $\mathrm{RJ} / \mathrm{kg} \mathrm{BW}$ caused to increase significantly $(P \leq 0$. 01) in $\operatorname{Ig} G$ and $\operatorname{Ig} M$ and primary and secondary antibody titer against sheep red blood cells (SRBC's) in hens as compared with100, $200 \mu \mathrm{g}$ of GA3and the control group. Injection $100,200 \mu \mathrm{g}$ of $\mathrm{GA3} / \mathrm{kg} \mathrm{BW}$ caused to increase significantly $(P \leq 0.05$ and $P \leq 0.01)$ in concentration of estrogen in hens and testosterone of cocks, FSH and LH in hens and cocks when compared with those in control group.

In conclusion, injection with 100, $200 \mu \mathrm{g} \mathrm{GA3} / \mathrm{kg}$ BW improved productive, reproductive and physiological performance of males and females Matrouh. Furthermore, the RJ-treated groups had significantly improved immune responses in hens and the quality of semen parameters in cocks under summer season conditions in Egypt.

Keywords: Gibberellic acid, Royal Jelly, Heat stress, Productive, Reproductive, Matrouh chicks.

\section{INTRODUCTION}

Heat stress is one of the most general environmental challenges to poultry local. It has been widely confirmed that heat stress negatively impacts the health, safety, and productivity of broilers and laying hens (Rostagno, 2020). Also, high ambient temperatures have clear impacts on the behavior, feed and water intake, heat production, and physiological responses (body temperature, respiratory rate and heart rate) of poultry (Mutibvu et al., 2017). Research has associated high environmental temperature with diminish fertility rate and sperm yield in reproducer cocks to high natural temperature (Obidi et al., 2008). The cooperative effect of heat in males with oxidative breakdown of sperm film lipids because of excess production of free radicals in sperm mitochondrial plasma layer have been watched (Sabeti et al., 2016). Gibberellic acid (GA3) is a characteristic hormone found in plants and parasites and goes as growth promoter (Silva et al., 2013). GA3 was seen as engaged with the union of RNA and proteins (Williams and Weisburger, 1991). In addition, Abdel-Azim (2017) announced that GA3 is one of the plant development controllers that are generally utilized in Egypt, to increase the growth of fruits and vegetables. Anderson et al. 
(1982) considered the impact injecting 72-weeks old brown egg type hens with $400 \mu \mathrm{g}$ of GA3 for 6 substitute days. They revealed a significantly greater mean of egg production that joined by $23 \%$ less feed expended per egg and a dynamic increment in egg numbers and weight with time until the 3ed week post injection at that point, it was slightly decreased from that point. Elkomy et al. (2007) presumed that, GA3 copy the estrogenic impact and it is skilled to animate estrogen secretion from the ovaries of hens at the end of productive stage and copy testosteronic biological effects for male chicks. Askar and Ismaell (2012) revealed that GA3 has a positive effect on productive performance and fertility of laying hens. Elkomy (2003) found that treated develop cockerels with GA3 directed to improve semen quality attributes (sperm concentration, sperm motility, increment live sperm and diminishing abnormal sperm). Likewise, who revealed that, the GA3 dosages had low serum testosterone concentration compare with the control group.

Royal Jelly (RJ) is item from honey bees that is utilized to take care of hatchlings in the hive just as a main nutritional source for the queen honey bee. It has different significant natural exercises including as an antioxidant, immunomodulatory, anti-inflammatory, antimicrobial, cholesterol-lowering, and growth promoter exercises and has the ability for inhibition of certain enzymatic corruption. It tends to be utilized for the improvement of growth performance, gut health and quality and safety of animal products in poultry because of its antioxidant and immune modulating properties (Saeed et al., 2018 and Zhang et al., 2019). The RJ is a rich source of proteins (27\%-41\%), essential amino acid (EAA), sugars (30\%), unsaturated fats, lipids (8\%-19\%), phytosterols, carotenes, flavonoids, nutrients and minerals that guide the honey bee to remain alive, just as some other unknown active compounds (Maghsoudlou et al., 2019). Moreover, the RJ organization can effectively decrease heat stress-induced reproductive damages through improvement of sperm attributes and MDA concentration restoration, proposing that $\mathrm{RJ}$ is a promising component to protect the reproduction in heat stress issue (Mahdivand et al., 2019). This bit of leeway is maybe a direct result of the presence of MRJPs in the RJ (Park et al., 2019). These properties supported the use of RJ as a well-known dietary enhancement and various pharmaceuticals related to fertility issue in animals (Maghsoudlou et al., 2019).

Therefore, the present study aimed to study the effect of gibberellic acid and royal jelly injection on some productive, reproductive and physiological traits in Matrouh chickens strain under Egyptian summer conditions. 


\section{MATERIALS AND METHODS}

The experimental work of this study was carried out at the Inshas Poultry Research Station, Animal Production Research Institute, Agricultural Research Center, Giza, Egypt, from May to August, 2019). One -hundered sixty eight laying hens and twenty one cocks of Matrouh local strain at 24 weeks of age (At $43.93 \%$ egg production) were used in a completely randomized design among seven treatment groups with three replicates in each treatment group ( 8 hens and 1 cock per replicate). Birds were housed in 21 floor pens $(2 \mathrm{~m} \times 2 \mathrm{~m})$ furnished with wheat straw and fed ad libitum a basal diet up to 36 weeks of age. The basal diet was formulated to meet the NRC (1994) recommendations as shown in Table 1.

The calculated analysis was according to Feed Composition Tables for Animal and Poultry Feedstuffs used in Egypt (2001) are shown in Table 1. Birds were submitted to the same managerial condition in a window house with light cycle regimen (16 hours light: 8 hours darkness). Birds were examined against diseases and treated with antibiotics and vaccines to keep them healthy. All groups had nearly similar average body weight (1218.36 \pm 5.39$)$ to investigate the effects of gibberellic acid and royal jelly injection on some productive, reproductive and physiological traits in local Matrouh chickens strain under Egyptian summer conditions. Birds are bi-weekly injected, for a whole experimental period. The $1^{\text {st }}$ treatment group of hens and cocks was injected with saline solution $0.9 \%$ only and served as control. The chicks in 2nd and 3rd treatment groups, were injected subcutaneously with $0.2 \mathrm{ml}$ of saline solution $0.9 \%$, which containing 100 and $200 \mu \mathrm{g}$ GA3/kg body weight (BW), respectively under the skin of the neck. While, the $4^{\text {th }}$ and $5^{\text {th }}$ treatment groups, were injected into the mouth, using an insulin syringe directly subcutaneously by 50 and $100 \mu \mathrm{g}$ Royal Jelly $(\mathrm{RJ}) / \mathrm{kg} \mathrm{BW}$, respectively. The $6^{\text {th }}$ treatment group was injected subcutaneously with $0.2 \mathrm{ml}$ of saline solution $0.9 \%$, which containing $100 \mu \mathrm{g}$ GA3/ $\mathrm{kg} \mathrm{BW}$ and injected into the mouth subcutaneously by $25 \mu \mathrm{g} \mathrm{RJ} / \mathrm{kg} \mathrm{BW}$. The $7^{\text {th }}$ treatment was injected subcutaneously with $0.2 \mathrm{ml}$ of saline solution $0.9 \%$, which containing $200 \mu \mathrm{g}$ GA3 $/ \mathrm{kg}$ BW and injected into the mouth subcutaneously by $50 \mu \mathrm{g} \mathrm{RJ} / \mathrm{kg} \mathrm{BW}$. The same 7 treatment groups were used also, on 21 cocks in individual batteries to take semen quality. 
Table (1): Composition and calculated analysis of the basal diet fed.

\begin{tabular}{|l|c|}
\hline \multicolumn{1}{|c|}{ Ingredients \% } & \% \\
\hline Yellow corn & 61.47 \\
\hline Soybean meal (44\% CP) & 15.20 \\
\hline Wheat bran & 8.28 \\
\hline Corn gluten meal (60\% CP) & 4.80 \\
\hline Dicalcium phosphate & 1.35 \\
\hline Salt & 0.30 \\
\hline Limestone & 8.20 \\
\hline Vit + Min. premix* & 0.30 \\
\hline DL-Methionine & 0.10 \\
\hline Total & $\mathbf{1 0 0}$ \\
\hline Calculated analysis : & \\
\hline Crude protein (CP); $\%$ & 16.19 \\
\hline ME; kcal/kg & 2687 \\
\hline Ether extract (EE) & 2.93 \\
\hline Crude fiber (CF) & 3.44 \\
\hline Calcium & 3.51 \\
\hline Av. Phosphorus & 0.30 \\
\hline Lysine & 0.65 \\
\hline Methionine & 0.39 \\
\hline Methionine + Cysteine & 0.69 \\
\hline
\end{tabular}

*Vitamin and Mineral premix: added to the $1 \mathrm{~kg}$ of diet including Vit. A 10000 I.U; Vit. D3 2000 I.U; Vit. E 15 mg; Vit. K3 1 mg; Vit. B1 1mg; Vit. B2 5 mg; Vit. B12 $10 \mu \mathrm{g}$; Vit. B6 1.5mg; Niacin 30mg; Pantothenic acid 10mg; Folic acid 1mg; Biotin $50 \mu \mathrm{g}$; Choline $300 \mathrm{mg}$; Zinc 50mg; Copper 4mg; Iodine $0.3 \mathrm{mg}$; Iron 30mg; Selenium 0.1mg; Manganese 60mg; Cobalt 0.1mg.

The average minimum and maximum of ambient temperature during the experimental period ranged between 25.21 and $36.45{ }^{\circ} \mathrm{C}$, relative humidity from 26.42 to $77.51 \%$ and temperature-humidity index (THI) from 22.77 to 34.93 under Inshas, Sharkia Governorate, Egypt as shown in Table 2.

THI was estimated according to the formula as follows:

$$
\mathrm{THI}=\mathrm{db}{ }^{\circ} \mathrm{C}-\left\{(0.31-0.31 \mathrm{RH})\left(\mathrm{db}{ }^{\circ} \mathrm{C}-14.4\right)\right\} \text {. }
$$


Table (2). Microclimatic data during the whole experimental period, under environmental conditions from Inshas, Sharkia Governorate, Egypt.

\begin{tabular}{|c|c|c|c|c|c|c|}
\hline \multirow{2}{*}{$\begin{array}{c}\text { Summer } \\
\text { months }\end{array}$} & \multicolumn{2}{|c|}{$\begin{array}{c}\text { Averages temperature } \\
\text { ('C) }\end{array}$} & \multicolumn{2}{c|}{$\begin{array}{c}\text { Averages } \\
\text { RH (\%) }\end{array}$} & \multicolumn{2}{c|}{$\begin{array}{c}\text { Averages } \\
\text { (THI) }\end{array}$} \\
\cline { 2 - 7 } & Min $^{*}$ & Max $^{* *}$ & Min $^{*}$ & Max $^{* *}$ & Min $^{*}$ & Max $^{* *}$ \\
\hline May & $21.99 \pm 0.52$ & $35.61 \pm 0.85$ & $19.55 \pm 1.26$ & $71.39 \pm 2.05$ & 20.10 & 33.73 \\
\hline Jun & $25.45 \pm 0.23$ & $36.34 \pm 0.38$ & $27.97 \pm 0.94$ & $78.67 \pm 1.26$ & 22.98 & 34.89 \\
\hline July & $26.61 \pm 0.21$ & $36.97 \pm 0.39$ & $29.0 \pm 1.19$ & $78.75 \pm 1.19$ & 23.92 & 35.48 \\
\hline August & $26.79 \pm 0.19$ & $36.91 \pm 0.32$ & $29.17 \pm 1.32$ & $81.23 \pm 1.46$ & 24.07 & 35.60 \\
\hline Averages & $25.21 \pm 0.28$ & $36.45 \pm 0.48$ & $26.42 \pm 1.17$ & $77.51 \pm 1.48$ & 22.77 & 34.93 \\
\hline
\end{tabular}

Where $\mathrm{db}{ }^{\circ} \mathrm{C}=$ Bulb temperature in Celsius and $\mathrm{RH}=\mathrm{RH} \% / 100$. The values obtained indicate the following: $<22.2=$ Absence of heat stress; 22.2 to $<23.3$ $=$ Moderate heat stress: 23.3 to $<25.6=$ Severe heat stress and 25.6 and more $=$ Extreme severe heat stress (Marai et al., 2000).

The body weight changes of laying hens calculated by the difference between finally and initial weight, while the egg number and egg weight were recorded daily and feed intake was calculated weekly. The egg production rate(EP) was calculated during the experimental period from 24 to 36 weeks of age. Where: $\mathrm{EP}$ rate $(\%)=\mathrm{EN} / \mathrm{hen} / \mathrm{x} 100$.

Egg mass (EM) was calculated by multiplying EN by average EW. Feed conversion (g feed/g egg) (FCR) was also calculated. The mortality rate $(\%)$ was recorded for daily each treatment from 24- 36 weeks of age.

Monthly, about 36 eggs from each treatment group were collected and incubated. After hatching, the chicks were counted and non-hatched eggs were broken to determine the overall mean of fertility and hatchability percentages. Fertility (\%) was calculated as the percentage of fertile eggs from the total number of set eggs, while the hatchability was expressed as the chicks hatched from fertile eggs and from total eggs.

At the end of the experimental period, $5 \mathrm{ml}$ blood samples were withdrawn from the brachial vein from 3 hens and 3 cocks per treatment group. 
Blood samples were collected in the morning from the overnight-fasted chickens. Each sample was collected in two tubs; one without anticoagulant, while in the other, heparin was used as an anticoagulant. Plasma and serum was obtained by centrifugation of blood at $1500 \times \mathrm{g}$ for $20 \mathrm{~min}$ and kept at -20 ${ }^{\circ} \mathrm{C}$ until used for analysis. The plasma concentrations of estrogen (E2), FSH, $\mathrm{LH}$ and testosterone (T) were measured using a homologous radioimmunoassay (Krishnan et al., 1993). Immunoglobulin concentrations of (IgG and IgM) were determined by enzyme-linked Immuno- sorbent assays using commercial ELISA kits according to manufacturer's Instructions (Sun Biomedical Technology Co., BeiJing, 10039).

Moreover, nine hens of each treatment group at 32 and 36 weeks of age were injected intravenously with $1 \mathrm{ml}$ of $10 \%$ suspension of sheep red blood cells (SRBC's). Then blood samples were collected at 33 and 37 weeks of age and centrifuged to get serum and frozen until the measurements of anti SRBC's antibody levels for primary and secondary immune responses were determined using micro-hemagglutination procedure (Witlin, 1967). The highest dilution exhibited by hemagglutination was recorded as titer of serum sample. The titer of each sample was converted to $\log 2$ value (Thaxton and Siegel, 1972).

After production of the primary egg, semen collected from the 7 groups of cocks twice every week. Semen was collected at three times amid the trial time frame at 28, 32 and 36 weeks of age from 5 cocks in each treatment group to determine the overall mean periods. Cocks were randomly chosen using the massage method. Immediately after semen collection, semenejaculate volume $(\mathrm{ml})$ was measured utilizing graduate collecting tubes and hydrogen-ion concentration $(\mathrm{pH})$ was measured by Universal Indicator Paper and Standard Commercial Stain. A drop of semen with the guide of a micropipette was set on a pre warmed microscope slide, which was then covered with a glass cover slip and inspected at a magnification of $\times 400$. Motility of semen samples was tested as the percentage of motile spermatozoa having moderate to rapid progressive movement and cells that are motile under their own power (Ommatiet al., 2013). At least 10 microscopic fields were inspected for every semen test. Eosin-Nigrosine stain was utilized to decide the percent of morphologically sperm abnormalities and dead spermatozoa. For sperm cell concentration (X $\left.10^{9} / \mathrm{ml}\right)$ a droplet of diluted semen $(1: 200$ in distilled water) semen was tenderly put on both councils of a Neubauerhemocytometer and the number of spermatozoa was determined 
microscopically (Ommatiet al., 2013). Acrosomal damage (\%) of spermatozoa was determined according to Waston (1975). No less than 10 minuscule fields were inspected for every semen test.

The economic efficiency (EEF) of the experimental treatments was estimated depending up on feeding cost and price of egg produced as the following equation:

$\operatorname{EEF}(\%)=($ Net revenue/hen $/$ Total cost hen $) \times 100$.

\section{Statistical analysis:}

Data were analyzed by the least square analysis of variance according to Snedecor and Cochran (1982) using the General Linear Model Procedure (SAS, 2011) at the 5\% level of significance as the following model:

$$
Y_{i j}=\mu+N_{i}+e_{i j}
$$

Where: $\mathrm{Y}_{\mathrm{ij}}=$ Any observation, $\mu=$ Overall mean, $\mathrm{N}_{\mathrm{i}}=$ Effect of treatment $(i=1 \ldots .7)$., $e_{i j}=$ Experimental random error. All percentages, data were transferred to percentage angle using arcsine equation before subject to statistical analysis. Significant differences among means were tested using Duncan's New Multiple Range Test (Duncan, 1955).

\section{RESULTS AND DISCUSSION}

\section{Productive performance:}

The effect of gibberellic acid, royal jelly and their mixtures injected on productive performance of Matrouh hens, during experimental periods under Egyptian summer conditions are presented in Table 3.

Body weight changes (BWC) of Matrouh layers injected with 100, 200 $\mu \mathrm{g}$ GA3, or $50,100 \mathrm{RJ} / \mathrm{kg}$ BW and their mixtures were significantly $(\mathrm{P} \leq 0.05)$ increased as compared with the control at the end of the experimental period.

The present results are in agreement with those reported by El-Sheikh and Hanafy (2006) who found that the live body weight of females and males of Bandarah local chicken strain injected with 250 or $500 \mu \mathrm{g}$ GA3 were significantly $(\mathrm{P} \leq 0.01)$ expanded particularly with the high dose during both treatments and recovery periods when compared with the control group. Marey (1974) showed that birds live body weight due to GA3 treatment was 


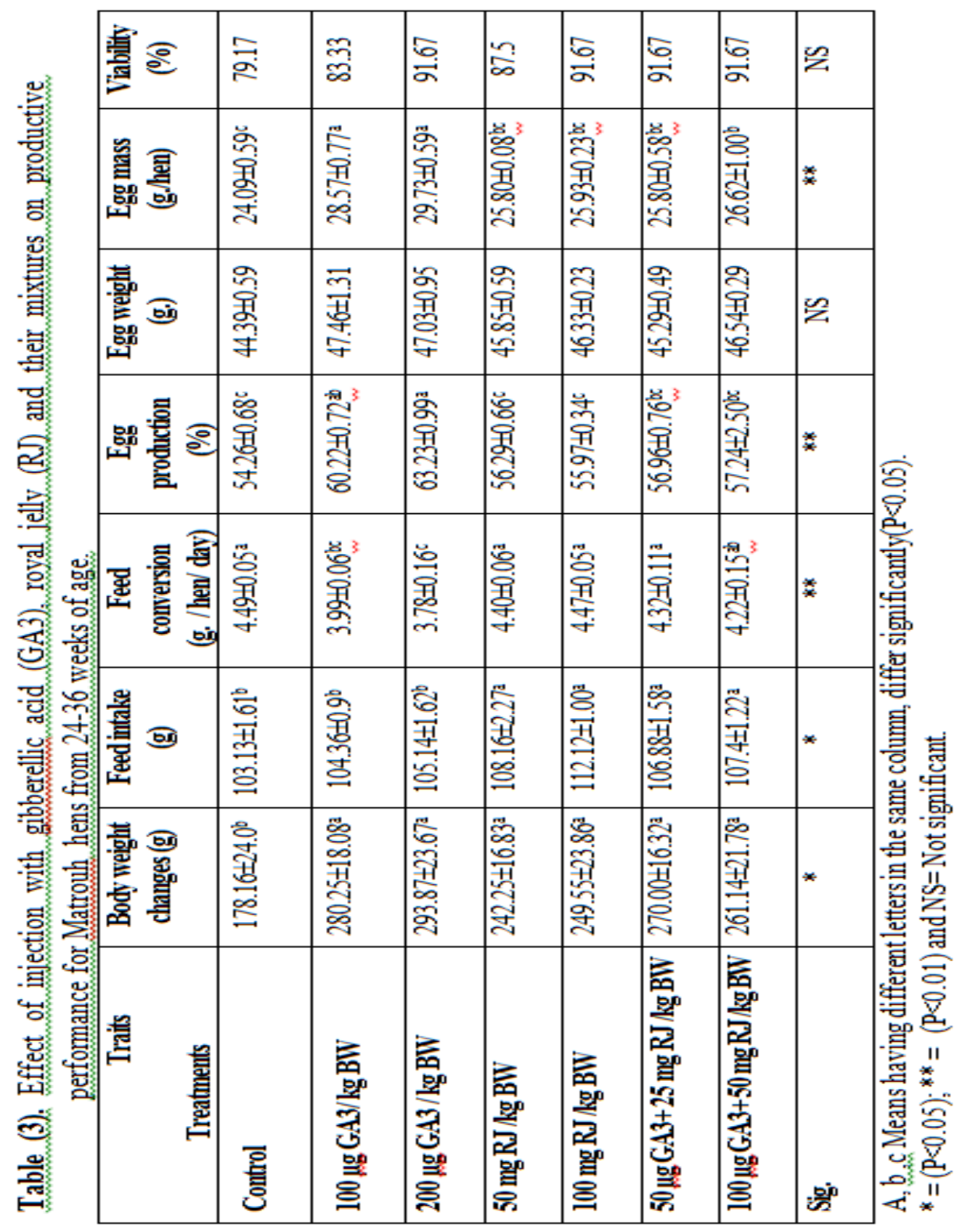


increased, this might be credited to GA3 physiological impact on guideline of the cell division; incitement of digestive enzymes production and creation of RNA and protein. Impacts of administrating RJ in trial animals were accounted for after its injection or ingestion, where the most apparent outcome was proposed to be the expanded BW turkey (Bonomiet al.,2001).On the other hand, Seven et al. (2016)detailed that the last weight of female quails in the RJ enhanced group (500 mg royal jelly/kg BW) was higher than in the control groups $(\mathrm{P}<0.05)$.

Seven et al. (2014) revealed that RJ improve growth performance of quails under stress resultant in increased BW and FI and lower FCR. The impact of these dynamic fixings, particularly flavonoids, on quails performance was accounted for beforehand (Bonomiet al., 2001; Seveniet al., 2012 and Seven et al., 2014). Saeed et al. (2018) found that supplementation with RJ at the level of 10 and $15 \mathrm{mg} / \mathrm{kg}$ in layer diets have showed a significant increase in body weight. The expanded last body weight of the RJ group might be linked to the expanding impact on oxygen digestion of tissues on account of expanded concentration and utilization of the blood glucose (Gonnard and N'Guyen, 1957). Notwithstanding this the expanding impact of RJ on tissue oxygen utilization cause last to improve final body weight and continuance because of the advancing impact of RJ on breath and oxidative phosphorylation (Krylov and Sokolskii, 2000).

Results uncovered that, viability percentage and egg weight (EW) of Matrouh layers injected with $100,200 \mu \mathrm{g}$ of GA3 or $50,100 \mathrm{RJ} / \mathrm{kg} \mathrm{BW}$ and their mixtures was not significantly affected and being higher than those control group. Layers injected by GA3/BW showed significantly $(\mathrm{P} \leq 0.05$ and $\mathrm{P} \leq 0.01)$ improved feed conversion ratio (FCR), egg production $(\mathrm{EP}) \%$ and egg mass (EM)when compared with those the $\mathrm{RJ} / \mathrm{kg} \mathrm{BW}$ and control group through the whole of the experimental period. The present results are in agreement with those reported by Elkomy et al. (2007) announced that with $100,200,400$ and $800 \mu \mathrm{g}$ GA3/kg BW to laying hens at 48 weeks old enough came about in marginally increment in hens FI when contrasted and the nontreated group without any significant impact of the amount. Anderson et al.(1982)found that GA3 treated group of 72 weeks old brown type hens significantly expanded egg production \% and egg weight. El-Sheikh and Hanafy (2006) demonstrated that the egg production percentage was 
significantly $(\mathrm{P} \leq 0.01)$ expanded, particularly with the low amount of GA3 ( $250 \mu \mathrm{g} \mathrm{GA} 3 / \mathrm{kg}$ body weight) during both treatment and recuperation periods contrasted and the control group and Elkomy et al.(2007)indicated a significant improvement in egg production of Gemiza hens that treated by GA3 where the moderate amount of GA3 $(200 \mu \mathrm{g})$ had the most elevated mean of egg production. This expansion in egg production may be due to the GA3 treated group had higher coursing estrogen hormone and the metabolic movement of GA3 improved ovulatory process (Anderson et al., 1982). As well as, Khalifa et al.(1983)inferred that; the improvement in egg production by estradiol can be clarified by the physiological impact of estrogen upon the ovary and oviduct which causing their activation and upgrading ovulatory process. Also, Saeed et al. (2018)found that the unsaturated fats, natural mixes and flavonoids in RJ have been appeared to upgrade the growth rate of quail resulting in improved body weight, feed intake and feed conversion ratio of layer hens. Hamdy et al.(2002)announced that, egg mass was significantly and decidedly related with plasma concentration of estrogen. Saeed et al. (2018)found that supplementation of RJ at the degree of 10 and $15 \mathrm{mg} / \mathrm{kg}$ in layer diets positively influenced egg weight (by $5.0 \%$ and $4.8 \%$,individually), egg production (10.5\% and $11.0 \%$,separately) and weight gain of hens $(7.0 \%$ and $6.5 \%$,separately).Additionally, Seven et al.(2016)who detailed that the feed consumption of RJ-supplemented groups was higher significantly than those of the control group. Seven et al. (2014)announced that these compound segments can improve growth performance of quail under pressure resulting in increased FI. Royal jelly has bunches of flavonoids, organic compounds and unsaturated fats.

\section{Reproductive performance:}

Percentages of fertile eggs, hatchability /total eggs and hatchability /fertility eggs of Matrouh hens injected with $100,200 \mu \mathrm{g}$ of GA3 or 50, 100 $\mathrm{RJ} / \mathrm{kg} \mathrm{BW}$ and their mixtures, under Egyptian summer conditions are presented in Table 4.

Diminishing of fertility percentage under heat stress might be because of that the heat stress could diminish numbered of spermatozoa put away in the sperm have an organ in the hen's regenerative tract (Brillard, 2003). Likewise, hatchability percentage was significantly lower $(\mathrm{P}<0.05)$ under heat stress, which might be because of the increment early stage demise during the brooding period because of increment endogenous (metabolic) heat creation 
EZZAT et al.

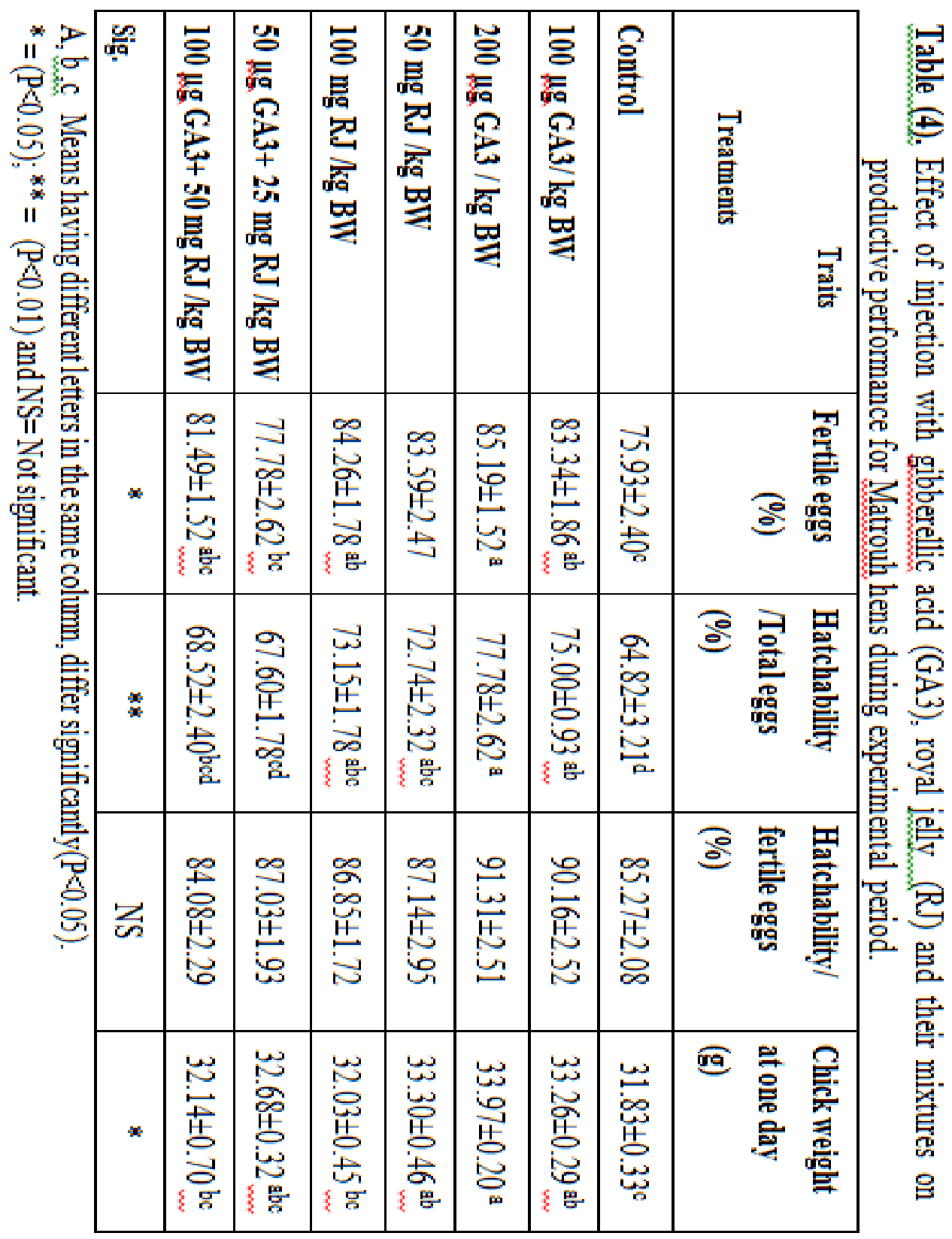


(Awad et al., 2013). In this investigation, the results indicated that hatchability/fertility eggs $\%$ of Matrouh layers injected with $100,200 \mu \mathrm{g}$ of GA3, $50,100 \mathrm{RJ} / \mathrm{kg} \mathrm{BW}$ and their mixtures were not significantly affected. However, fertility eggs $\%$, hatchability/total eggs $\%$ and chicks hatch weight (g) were significantly $(\mathrm{P}<0.05$ and $\mathrm{P}<0.01)$ higher for layers injected with 100 , $200 \mu \mathrm{g}$ of GA3 or $50,100 \mathrm{RJ} / \mathrm{kg} \mathrm{BW}$ as compared with those in the control group. These results agreed with those of Askar and IsmaeIl (2012) revealed that fertility percentage of laying hens was affected significantly $(\mathrm{P}<0.05)$ by GA3 treatment, where hens that injected by $400 \mu \mathrm{g}$ of GA3 showed the highest value $(86.67 \%)$ with $29 \%$ more than that of control group $(66.67 \%)$. El-Sebai et al. (2003), demonstrated that GA3 treatment had a little and insignificant effect on fertility percentage of female Japanese quails, while hatchability one was significantly $(\mathrm{P}<0.05)$ improved due to GA3 treatment. These results might be because of the great semen quality characteristics of the cocks treated with injected with $100,200 \mu \mathrm{g}$ of GA3 kg BW. The improvement in fertility; hatchability and chick characteristics might be ascribed to the helpful impacts of GA3 on egg quality, since part of the metabolic activity in birds is prompting an expansion in estrogen levels and additionally produce direct estrogen-like activity (Gawienwski and Chatterijee, 1980).

On the other hand, the improvement of fertility rates and hatchability/total eggs in heat-stressed animals that treated with RJ could be attributable to the significant compounds of RJ for example proteins, micronutrients, antioxidants and phenolic that enhance liver and kidneys work to decrease in lipid peroxidation and oxidative stress synthesis (Abdelnour et al., 2020). RJ can have the option to restrain the creation of Reactive Oxygen Species (ROS) and protein oxidation (El-Hanoun et al., 2014 and Elnagar, 2010). EL-Tarabany et al. (2017) revealed that RJ may improve the negative effects of senescence in laying hens at the late phase of production.

\section{The immunoglobulin, IgG, IgM and sheep red blood cells (SRBC's) :}

It's known, heat stress significantly decreases the plasma levels of IgA, IgG and IgM in chickens (Chen, 2015). This decrease of antibody titer with heat stress be credited to the arrival of a continued elevated level of corticosterone bringing about diminished IgM and IgG combination (Habibian et al., 2013). Figures (1 and 2) exhibited that immunoglobulin $\mathrm{G}$ ( $\mathrm{IgG}$ ), immunoglobulin $\mathrm{M}$ (IgM) and primary and secondary antibody titer against sheep red blood cells (SRBC's), in hens Matrouh injected with 100, $200 \mu \mathrm{g}$ of 


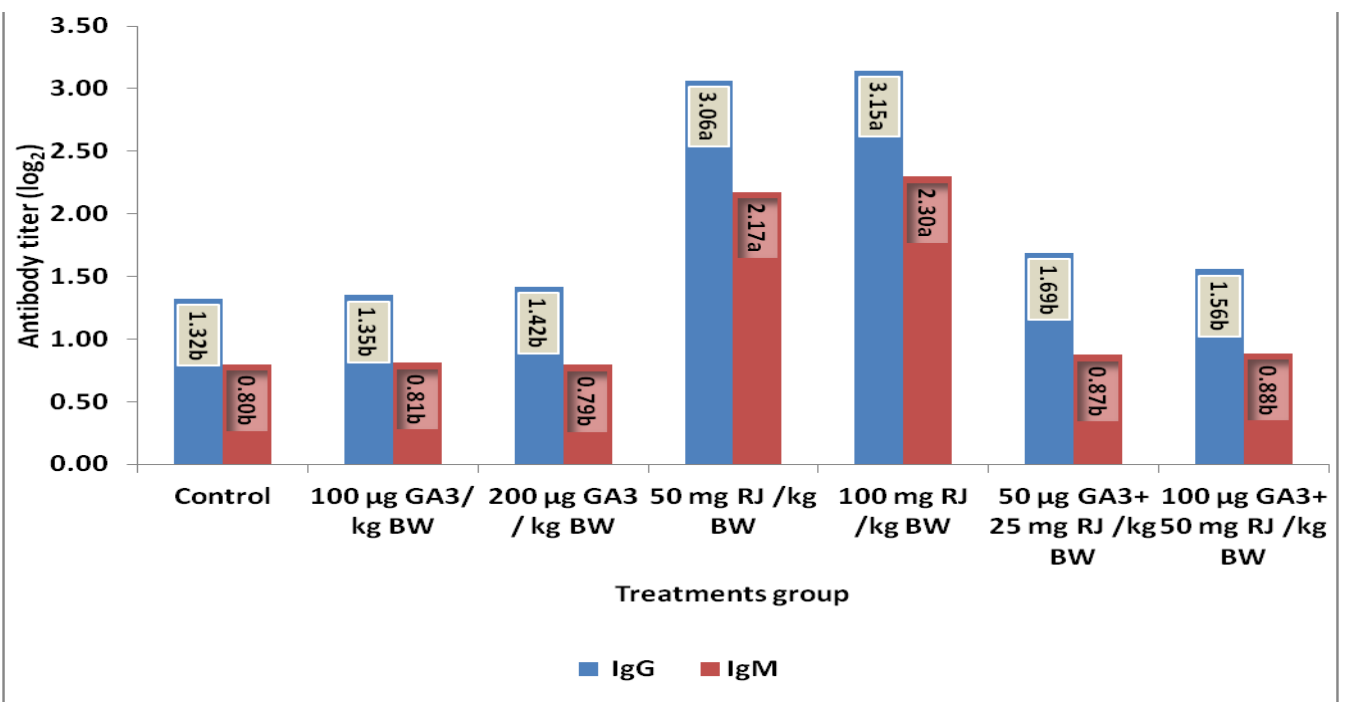

Figure (1): $\operatorname{IgG}$ and $\operatorname{IgM}$ antibody titre ( $\left.\log _{2}\right)$ as affected by gibberellic acid and royal jelly and their mixtures injection in Matrouh hens strain under Egyptian summer conditions.

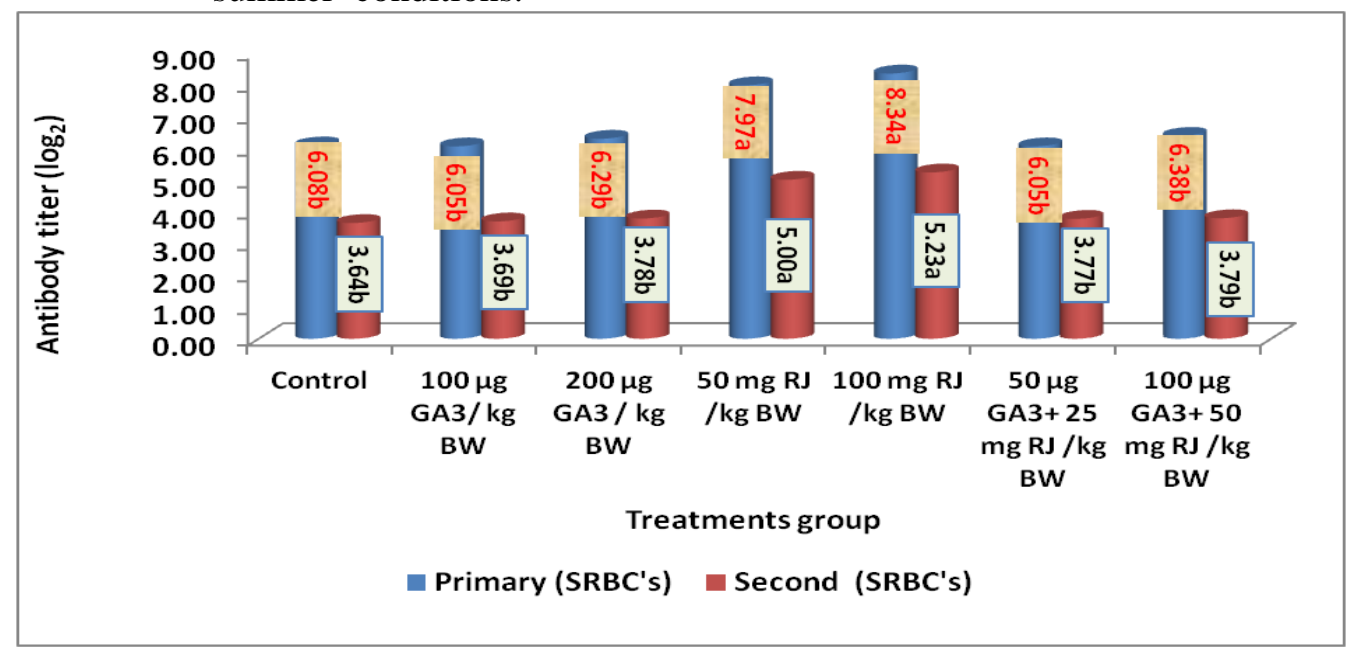

Figure (2): Primary and secondary antibody titer against sheep red blood cells (SRBC's) as affected by gibberellic acid and royal jelly and their mixtures injection in Matrouh hens strain under Egyptian summer conditions. 
GA3 / kg BW only or mixtures with the levels of $50,100 \mathrm{RJ} / \mathrm{kg}$ BWRJ were not significantly affected. However, injection $50,100 \mu \mathrm{g}$ of $\mathrm{RJ} / \mathrm{kg} \mathrm{BW}$ caused to significantly $(\mathrm{P} \leq 0.01)$ increased in $\mathrm{IgG}, \mathrm{IgM}$ and primary and secondary antibody titer against sheep red blood cells (SRBC's) in hens. The improvement of the immune system might be RJ contains amino and gamma globulin, unsaturated fats, hormones, catalysts, proteins, nutrient $\mathrm{E}$ and $\mathrm{A}$ that help the invulnerable framework battle disease (Crenguta et al., 2011). These results agreed with those of Mufarrej and Ei- Sarag (1997)saw that directed RJ (200 mg) significant increased antibody production against SRBC's in chickens when contrasted with the control group. Taha et al. (2019)announced that RJ injection in ovo at levels 0.25 and $0.5 \mathrm{ml} / \mathrm{egg}$ upgraded antibody titres against SRBC's of chicken strains El-Salam and Dokki-4 when contrasted with partner control chicks. Similarly, Elnagaret al. (2010)found that RJ treatments expanded IgG and IgM levels in heat-stressed growing rabbits. ElHanoun et al. (2014) announced that treated heat-stressed male rabbits with 50,100 and $150 \mathrm{mg} \mathrm{RJ} / \mathrm{kg} \mathrm{BW}$ significantly $(\mathrm{P}<0.05)$ increased sheep red blood cells (SRBC's), IgG, IgM and IgA levels, and this expansion was dosedependent as compared with the control group.

\section{Some blood serum hormones concentration:}

Blood serum estrogen, FSH, LH in females and testosterone, FSH and LH in males Matrouh injected with $100,200 \mu \mathrm{g}$ of GA3 or50 , $100 \mathrm{RJ} / \mathrm{kg}$ BW and their mixtures during hot summer condition are presented in Table 5. In this investigation, the outcomes indicated that blood serum estrogen, FSH, LH in hens and FSH and LH in the cocks of Matrouh layers injected with 50 , $100 \mathrm{RJ} / \mathrm{kg} \mathrm{BW}$ only or mixtures with the levels of GA3were not significantly affected. In any case, injection $100,200 \mu \mathrm{g}$ of GA3 $/ \mathrm{kg} \mathrm{BW}$ caused to significantly $(\mathrm{P} \leq 0.05$ and $\mathrm{P} \leq 0.01)$ increased in concentration of estrogen in hens and testosterone of cocks, FSH and LH in hens and cocks compared with those in control groups. These results agreed with those of Elkomy (2003) who revealed that GA3 can stimulate estrogen emission in hens. Elkomy et al. (2007)presumed that gibberellic acid can have both estrogenic organic impacts on female chicks and testosterone natural consequences for male chicks. The reason for the high levels of estrogen in the blood serum of the two female injections might be ascribed to the job of gibberelic acid in stimulating the ovaries to discharge estrogen (Elkomy et al., 


\begin{tabular}{|c|c|c|c|c|c|c|c|c|c|c|c|}
\hline 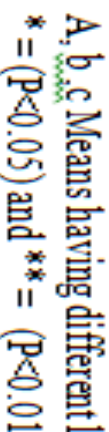 & 몀 & 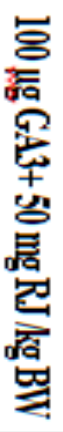 & 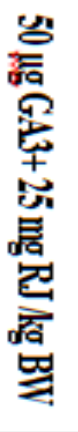 & 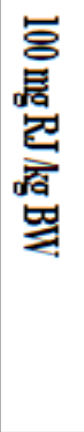 & 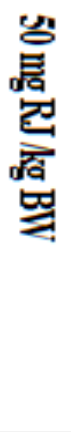 & 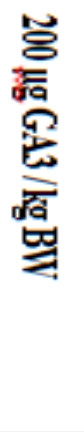 & 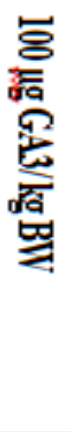 & 言 & $\begin{array}{l}\text { 蒫 } \\
\text { 官 } \\
\text { 蛋 }\end{array}$ & 隺 & \\
\hline 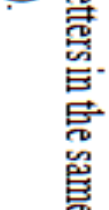 & * & 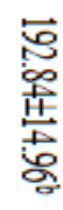 & 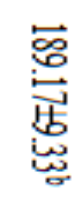 & 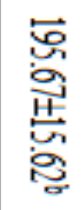 & 䓞 & 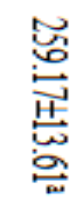 & 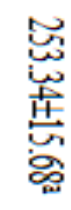 & 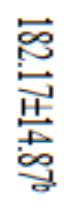 & 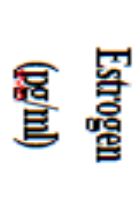 & \multirow{3}{*}{ 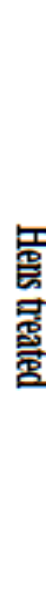 } & \\
\hline $\begin{array}{l}\text { 总 } \\
\text { 恶 } \\
\text { 亮 }\end{array}$ & * & 岕 & 芯 & 蒠 & 웅 & 莕 & 䍃 & $\begin{array}{l}\text { 웅 } \\
\text { 葛 }\end{array}$ & 察 四 & & 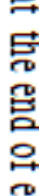 \\
\hline 穿 & * & 点 & 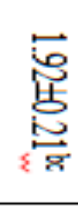 & 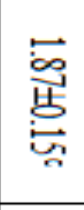 & 营 & 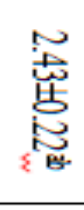 & 总 & 突 & 焉 & & \\
\hline 잉 & * & 总 & $\begin{array}{l}\text { 造 } \\
\text { 总 } \\
\text { 。 }\end{array}$ & 总 & 岕 & 冚 & $\underset{\omega}{\omega}$ & 岂 & 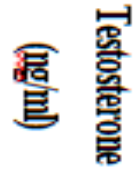 & \multirow{3}{*}{ 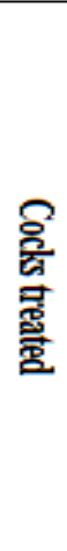 } & \\
\hline & * & $\begin{array}{l}\text { 兽 } \\
\text { 营 }\end{array}$ & $\begin{array}{l}\text { 웅 } \\
\text { 章 } \\
\text { 양 }\end{array}$ & $\begin{array}{l}\text { 유 } \\
\text { 옹 } \\
\text { 总 } \\
\text { 응 }\end{array}$ & $\begin{array}{l}\text { 영 } \\
\text { 蓉 } \\
\text { 。 }\end{array}$ & 畧 & 点 & $\begin{array}{l}\text { 웅 } \\
\text { 웅 } \\
\text { 잉 }\end{array}$ & 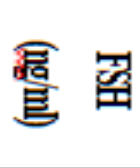 & & \\
\hline & $*$ & 品 & 总 & 雚 & 总 & 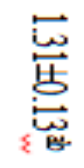 & 点 & $\begin{array}{l}\text { 윰 } \\
\text { 总 } \\
\text { ○्र }\end{array}$ & 自䁹 & & \\
\hline
\end{tabular}


2007).The purpose behind the high concentration of hormone testosterone in the blood serum of male might be because of the high rates of weights, sizes of testicles for these birds and testosterone fixation (Garamszegi et al., 2005). Elkomy et al. (2007) showed a significant level of FSH, LH hormone in the serum of old female chickens who were injected with gibberellic acid at a concentration of $200,400 \mu \mathrm{g} / \mathrm{kg}$ of body weight compared to the control group. The explanation behind the significant levels of FSH and LH hormones in female and male blood serum injections might be due to the expansion in testosterone in the male blood serum and estrogen in the female blood serum, which was appeared by Tsuisui and Ishii, (1980) who found that FSH and testosterone of Japanese quail increase FSH official by Sertoli cells, and together apply a synergistic impact on FSH binding. The effect of RJ on testosterone is in agreement with the findings of Elnagar (2010)demonstrating a significant increment in testosterone level when heat stressed male rabbits were orally managed 200, 400 and $800 \mathrm{mg} \mathrm{RJ} / \mathrm{kg} \mathrm{BW}$. El-Hanoun et al. (2014) revealed that treated heat-stressed buck rabbits with 50,100 and $150 \mathrm{mg} \mathrm{RJ} / \mathrm{kg}$ BW supported blood testosterone concentration to arrive at 10, 20 and $28 \%$, separately, over the untreated group values.

\section{Semen physical characteristics:}

Semen ejaculate volume, hydrogen-ion concentration $(\mathrm{pH})$, sperm motility, dead spermatozoa, sperm abnormalities (\%), sperm cell concentration $(\mathrm{X} 10 \% \mathrm{ml})$ and acrosomal damage (\%) of Matrouh cocks injected with 100 , $200 \mu \mathrm{g}$ of GA3, 50, $100 \mathrm{RJ} / \mathrm{kg} \mathrm{BW}$ and their mixtures, under Egyptian summer conditions are presented in Table 6 .

Semen ejaculate volume and hydrogen-ion concentration $(\mathrm{pH})$ of cocks were not significantly affected by the injection of GA3, RJ $/ \mathrm{kg} \mathrm{BW}$ and their mixtures. However, injection of $100,200 \mu \mathrm{gGA} 3,50,100 \mathrm{RJ} / \mathrm{kg} \mathrm{BW}$ and their mixtures caused to improve significantly $(\mathrm{P}<0.05) \quad$ sperm-cell concentration $(\mathrm{X} 10 \% / \mathrm{ml})$ and sperm motility $(\%)$, while significantly $(\mathrm{P}<0.05)$ decreased each of dead spermatozoa (\%), sperm abnormalities (\%), and acrosomal damage (\%) as compared with the control group. The improvement of semen physical properties might be GA3 animating spermatogenesis prose or /and may be have direct testosterone-like action on testicles, thus initiate enactment of testicular germinal epithelium in the seminiferous tubules (El-Sheikh and Hanafy, 2006). These results agreed with those of Elkomy 


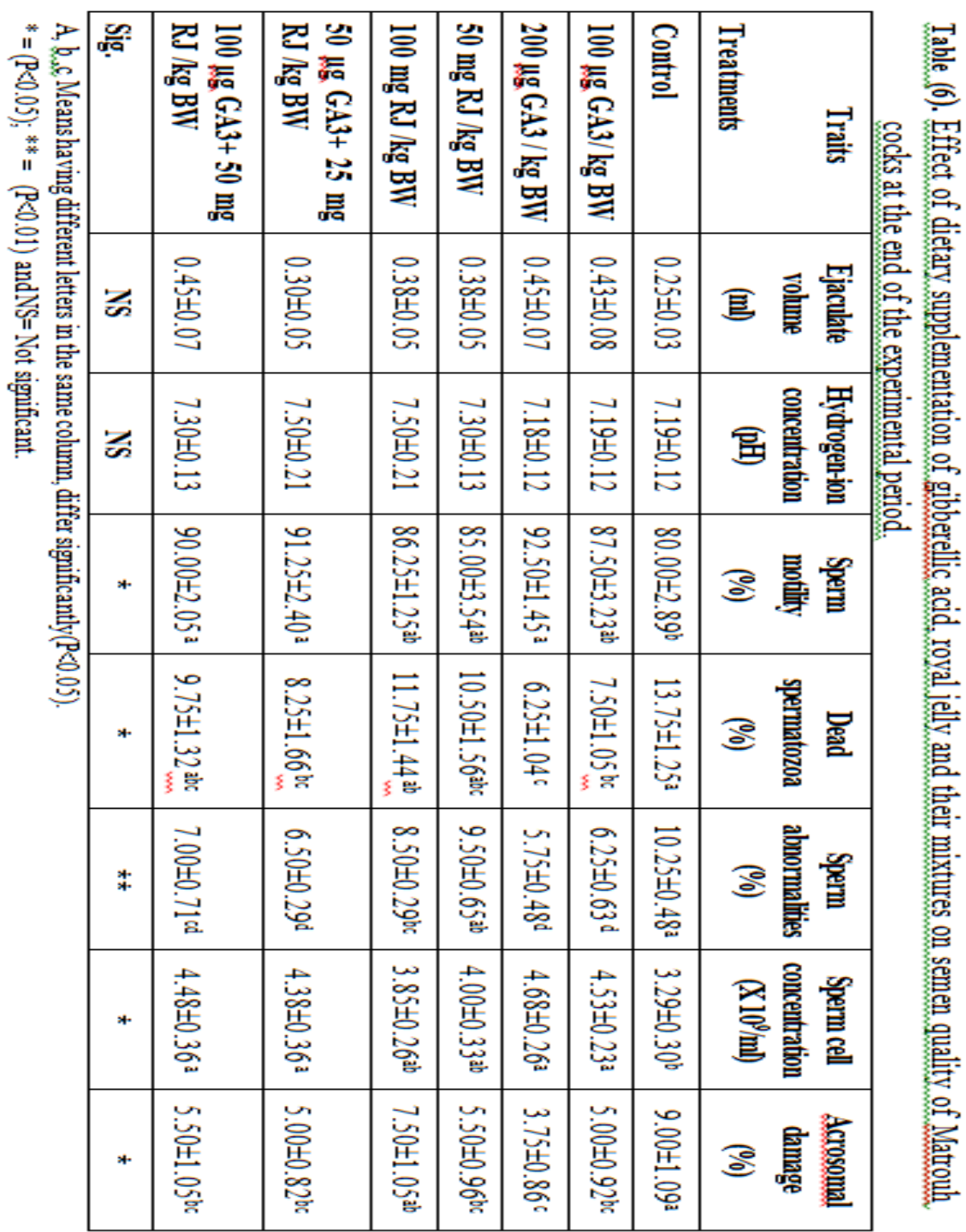


(2003)found that treated develop cockerels with GA3 conducted to improve semen quality attributes (sperm concentration, sperm motility increase live sperm and decrease abnormal sperm). GA3 improved semen attributes and has a constructive effect on semen quality and amount. These perceptions allude to that GA3 might be caused animating and supporting spermatogenesis process in seminiferous tubules to create spermatozoa and furthermore, sex embellishment organs to discharge original plasma (Kamel et al., 2009).

On the other, hand, Elnagar (2010), who detailed that the oral organization of RJ can check summer infertility (significant improvement of a series of spermography parameters) and improve the physiological status in male rabbits. The improvement in motility of sperm might be because of the increase in the level of testosterone that is responsible for sperm motility (Table 6).

Economical efficiency(\%):

Data shown in Table (7) clear that Matrouh layers injected with $200 \mu \mathrm{g}$ of GA3 $/ \mathrm{kg}$ BW were recorded the highest net revenue and the best economical efficiency followed by those $100 \mu \mathrm{g}$ of GA3/kg BW as compared with the control groups, while 50 or $100 \mu \mathrm{g}$ of $\mathrm{RJ} / \mathrm{kg} \mathrm{BW}$ had the lowest net revenue and economical efficiency (\%).

Conclusively, data revealed that injection with 100, $200 \mu \mathrm{g}$ GA3 $/ \mathrm{kg} \mathrm{BW}$ of caused to improving productive, reproductive and physiological performance of males and females Matrouh. Furthermore, the RJ-treated groups had significantly improved immune responses in hens and the quality of semen parameters in cocks under summer season conditions in Egypt.

\section{REFERENCES}

Abdel-Azim, B.A. 2017. Toxicological study of gibberellic acid on liver, kidney and brain and its apostasy in adult albino rats. Res. J. Pharm. Biol. Chem. Sci., ㅇ:443-450.

Abdelnour, S. A.; Abd El-Hack, M. E.; Alagawany, M.; Taha, A. E.; Elnesr, S. S.; Abd Elmonem, O. M. and Swelum, A. A. 2020. Useful impacts of royal jelly on reproductive sides, fertility rate and sperm traits of animals. J. Anim. Physiol. Anim. Nutr., 00:1-11. 


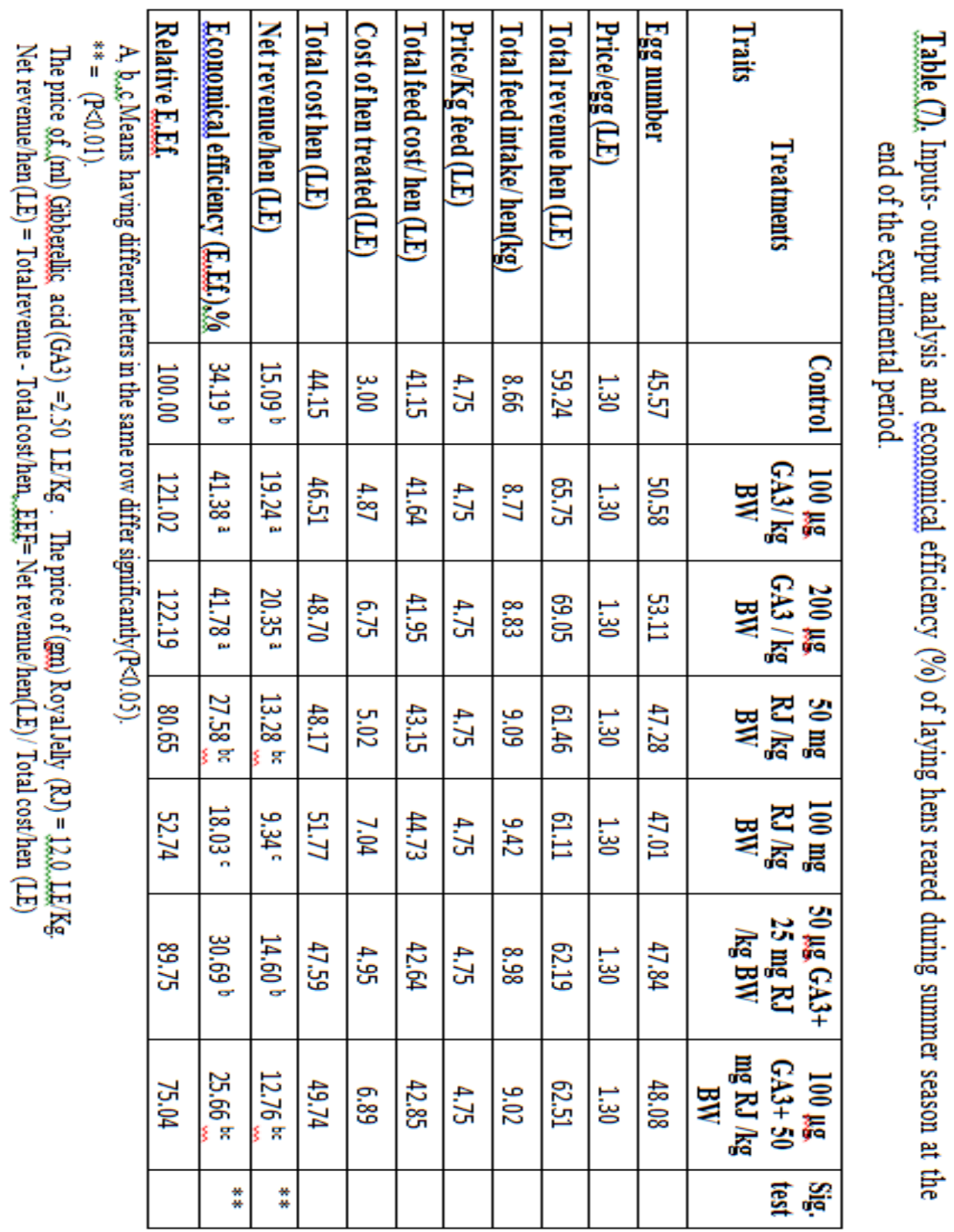


Andreson, D.L.; Witkowsky, R.D. and Gawienowski, A.M. 1982. Effect of gibberellic acid on production characteristics of aged and force molted chickens in cages. Poultry Sci., 61: 1660-1666.

Askar, A.A. and IsmaeIl, E.I. 2012. Effect of gibberellic acid on some physiological; reproductive and hatchability parameters of laying hens during winter and summer seasons. Egypt. J. Anim. Prod., 49 (1):77-86.

Awad, A. L.; Fahim, H. N.; Ibrahim, A.F. and Beshara, M.M. 2014 . Effect of dietary betaine supplementation on productive and reproductive performance of domyati ducks under summer conditions. Egypt. Poultry Sci., 34: 453-474.

Bonomi, A.; Bonomi, B.M. and Quarantelli, A. 2001. Royal jelly in turkey feeding; Royal jelly in guinea-fowl feeding. Riv. Sci. Anim. 30: 49-60.

Brillard, J.P. 2003. Practical aspects of fertility in poultry. World's Poultry Sci. J., 59: 441-446.

Chen, Z.; Zhang, J.R.; Zhou, Y.W.; Liang, C. and Jiang, Y.Y. 2015. Effect of heat stress on the pituitary and testicular development of Wenchang chicks. Arch. Anim. Breed., 58: 373-378.

Crenguța, I.P.; Liviu, A.I.M.; Otilia, B.; Daniel, S.D.; Agripina, Ş.; Ion, R. and Mariana, N.M. 2011. Biological Activities of Royal Jelly. Review. Anim. Sci. Biotech., 44: 108-118.

Duncan, D.B., 1955. Multiple range and multiple F tests. Biometrics, 11:1-42.

El-Hanoun, A. M.; Elkomy, A. E.; Fares, W. A. and Shahien, E. H. 2014. Impact of royal jelly to improve reproductive performance of male rabbits under hot summer conditions. World Rabbit Sci., 22( $\underline{\mathbf{3}}), 241-$ 248.

Elkomy, A. 2003. Physiological studies on Gibberellic acid (AG3) and reproduction function of adult fowl. Ph. D. Thesis. Faculty of Agric., Alexandria University, Alexandria. Egypt.

Elkomy, A.E., A. Samar Elnagar and Azza El-Sebai, 2007. Steroidogenic effects of gibberellic acid (GA3) on chicks. Egypt. Poultry Sci., 27(4): 1239-1255.

EInagar, S.A. 2010. Royal jelly counteracts bucks "summer infertility". Anim. Reprod. Sci., 121: 174-180.

El-Sebai, A.; Abaza, M. and Elnagar S. A. 2003. Physiological effects of "Gibberellic acid (GA3)" on female Japanese quail production and reproduction. Egypt. Poultry Sci., 23:977-992. 
El-Sheikh, A.M.H. and Hanafy, M. M. 2006. Physiological effects of gibberellic acid (GA3) on some productive and reproductive traits of Bandarah local chicken strain. Egypt. Poultry Sci., $\underline{\mathbf{6}}$ 1071-1087.

EL-Tarabany, M.S. 2017. Effect of Royal Jelly on behavioural patterns, feather quality, egg quality and some haematological parameters in laying hens at the late stage of production. J. of Anim. Physiology and Anim. Nutr., 102: 599-606.

Feed Composition Tables For Animal and Poultry Feedstuffs Used In Egypt 2001. Technical bulletin No.1, central lab for Feed and food; Ministry of Agric., Egypt. .

Garamszegi, L.Z.; Eens, M.; Hurtrez-Bousses, S. and Mbller, A.P.2005. Testosterone, testes size, and mating success in birds: comparative study. Horm. and Behav., 47 : 389-409.

Gawienowski, A.M. and Chatterijee, D. 1980. Effect of prostaglandin inhibitor on the uterotrophic response of estradiol and gibberellic acid. Life Sci., 27: 1393-1396.

Gonnard, P. and N'Guyen, C.C. 1957. Action of royal jelly on oxygen consumption in tissues in vitro. Ann. Pharmacol. Fr., 15, 383-393.

Habibian, M.; Ghazi, S.; Moeini, M.M. and Abdolmohammadi, A. 2013. Effects of dietary selenium and vitamin $\mathrm{E}$ on immune response and biological blood parameters of broilers reared under thermoneutral or heat stress conditions. Int. J. Biometeorol., 5: 1426-1437.

Hamdy, A.M.M; Esa, N.M. and Bakir, A.A. 2002. Prediction of egg production by some body measurments and plasma steroids hormones. Egypt. Poultry Sci., 22: (1) 205-218.

Kamel, K.I.; Elkomy, A.E. and El-Sbeiy, M.E. 2009. The androgenic action of gibberellic acid (GA3 ) on reproductive performance of New Zealand White Rabbit Bucks. World J. of Agri. Sci. 5 (1): 40-48.

Khalifa, M.A, M.K Shebaita, G.A.R. Kamar and M.A. Abdou, 1983. Effect of thyroxin, estradiol and ACTH on egg characters and some reproductive organs in Fayoumi. Egypt. J. Anim. Prod., 23: 95-107. 
Krishnan, K. A.; Proudman, J. A. and Bolt, D. J. 1993. Development of a homologous radioimmunoassay for chicken follicle-stimulating hormone and measurement of plasma FSH during the ovulatory cycle. Comparative Biochemistry and Physiology. Comparative Physiology, 105(4), 729-734.

Krylov, V. and Sokolskii, C. 2000: Royal jelly (in Russian). Agroprompoligrafist Krasnodar. Pp. 214.

Maghsoudlou, A.; Mahoonak, A. S.; Mohebodini, H. and Toldra, F. 2019. Royal jelly: Chemistry, storage and bioactivities. J. of Apic. Sci., 63 (1), 17- 40 .

Mahdivand, N.; Najafi, G.; Nejati, V.; Shalizar-Jalali, A. and Rahmani, F. 2019. Royal jelly protects male rats from heat stress-induced reproductive failure. Andrologia, 51(ㅉ), 13213.

Marai, I.F.M.; Bahgat, L.B.; Shalaby, T.H. and Abdel-Hafez, M.A. 2000. Fattening performance, some behavioral traits and physiological reactions of male lambs fed concentrates mixture alone with or without natural clay under hot summer of Egypt. Ann. Arid Zone (India) $\underline{39}$ : 449-460.

Marey, N.M.S. 1974. Proceeding of the 1st meeting of the Egyptian Horticulture society on growth regulators. Cairo, 28 Nov. 1972.

Mufarrej, S.I. and Ei- Sarag, M.S.A. 1997. Effects of royal jelly on the humoral antibody response and blood chemistry of chickens. J. Appl Anim. Res.,12: 41-47.

Mutibvu, T.; Chimonyo, M. and Halimani, T.E. 2017. Physiological responses of slow-growing chickens under diurnally cycling temperature in a hot environment. Braz. J. Poultry Sci., 19: 567-576.

NRC, 1994. Nutrient Requirements of Poultry. $9^{\text {th }}$ Rev. ed. National Academy Press, Washington, DC.

Obidi, J.A.; Onyeanusi, B.I.; Rekwot, P.I.; Ayo, J.O.; Dzenda, T. 2008. Seasonal variations in seminal characteristics of Shikabrown breeder cocks. Int. J. of Poultry Sci., 7: 1219-1223.

Ommati, M. M.; Zamiri, M. J.; Ākhlaghi, A.; Atashi, H.; Jafarzadeh, M. R.; Rezvani, M. R. and Saemi, F., 2013. Seminal characteristics, sperm fatty acids, and blood biochemical attributes in breeder roosters orally administered with sage (Salvia officinalis) extract. Anim. Prod. Sci., 53:548-554. 
Park, M. J.; Kim, B. Y.; Park, H. G.; Deng, Y.; Yoon, H. J.; Choi, Y. S.; Lee, K.S. and Jin, B. R. 2019. Major royal jelly protein 2 acts as an antimicrobial agent and antioxidant in royal jelly. J. of Asia-Pacific Entomol., 22( 3), 684- 689.

Rostagno, M.R. 2020. Effects of heat stress on the gut health of poultry. Journal of Animal Science, 98 (4): 1-21.

Sabeti, P.; Pourmasumi, S; Rahiminia,T.; Fatemeh Akyash,F. and Ali Reza Talebi, A.R. 2016. Etiologies of sperm oxidative stress. Int J. Reprod. Bio. Med., 14(4): 231-240.

Saeed, M.; Kalhoro, S.A.; Naveed, M.; Hassan, F.U.; Umar, M.; Rashid, M.; Memon, S.A.; Soomro, F.; Arain, M.A. and Chao, S. 2018. Prospects of royal jelly as a potential natural feed additive in poultry diets. World's Poultry Sci. J., 74:1-11.

SAS (2011). Base SAS 9.3 Procedure Guide: Statistical Procedure. Cary, NC, USA.

Seven, I.; Şimşek, U.G.; Gokçe, Z.; Seven, P.T.; Arslan, A. and Yilmaz, O. 2014. The effects of royal jelly on performance and fatty acid profiles of different tissues in quail (Coturnix coturnix japonica) reared under high stocking density. Turkish J. of Vet. and Anim. Sci. 38: 271-277.

Seven, P. T.; Sur Arslan, A.; Özçelik, M.; Gülcihan Şimşek, Ü. and Seven, I. 2016. Effects of propolis and royal jelly dietary supplementation on performance, egg characteristics, lipid peroxidation, antioxidant enzyme activity and mineral levels in Japanese quail. European Poul. 80:138.

Seveni, I; Slmsek, G.; Gokce Z, et al., 2012. The effects of royal jelly on performance and fatty acids profiles of different tissues in quail (Coturnix Japonica) reared under high stocking density. Turk. J. Vet. Anim. Sci., 38: 271-277.

Silva, A.L.L.; Rodrigues, C.; Costa, J.L.; Machado, M.P.; Penha, R.O.; Biasi, L.A.; Vandenberghe ,L.P.S. and Soccol, C.R. 2013. Gibberellic acid fermented extract obtained by solid-state fermentation using citric pulp by Fusarium moniliforme: Influence on Lavandula angustifolia Mill. cultivated in vitro. Pakistan J. of Botany. 45 (ㅁ) : 2057-2064.

Snedecor, G.W. and Cochran, W.G. 1982. Statistical Methods. 7th Edition, Iowa State University Press, Towa, 511. 
Taha , A. E.; AbdAllah, O. A.; Attia, K.M.; R. E. Abd El-Karim, R. E.; Abd El-Hack, M. E.; El-Edel, M. A., Saadeldin, I. M.; Hussein, E.O.S. and Swelum, A. A. (2019). Does in ovo injection of two chicken strains with royal jelly impact hatchability, post-hatch growth performance and haematological and immunological parameters in hatched chicks? Animals, 9, 486:1-14.

Thaxton, J.P. and Siegel, H.S. 1972. Depression of secondary immunity by high environmental temperature. Poultry Sci., 51:1519-1526.

Tsutsui, K. and Ishii, S. 1980. Hormonal regulation of follicle-stimulating hormone receptors in the testes of Japanese quail. J. Endocrinol., 85: 511-518.

Watson, P. F. 1975. Use of Giemsa stain to detect changes in acrosomes of freezing ram spermatozoa. Vet. Res., 97:12-15.

Williams G.M. and Weisburger, J.H. 1991. Chemical Carcinogenesis. In: Casarett and Doull's Toxicology: The Basic Sciences of Poisons. Eds. Klaassen, CD., Amdur, MO. and Doull, J. ( $4^{\text {th }}$ ed.). Pergamon Press, New York, 127-200.

Witlin, B. 1967. Detection of antibodies by microtitration techniques. Mycopathol. Mycol. Appl., 33:214-257.

Zhang, X.; Yu, Y.; Sun, P.; Fan, Z.; Zhang, W. and Feng, C. 2019. Royal jelly peptides: Potential inhibitors of $\beta$-secretase in N2a/APP695swe cells. Scientific Reports, 9(1), 168.

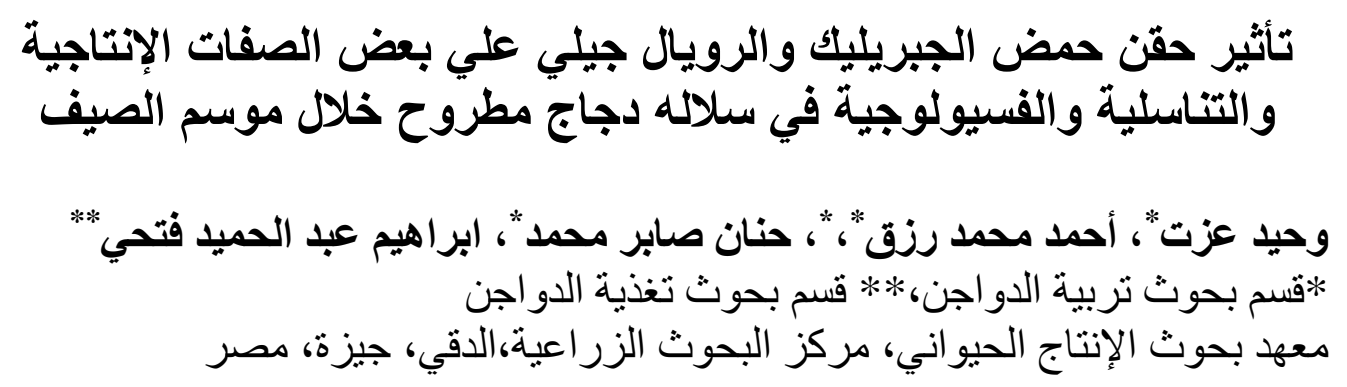

تم استخدام 168 دجاجة بياضه و 21 ديك من سلالة مطروح المحلية عند عمر 24 عن في

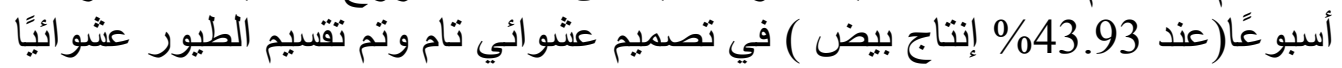

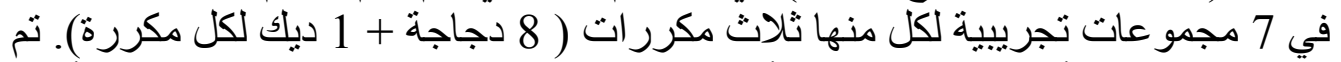

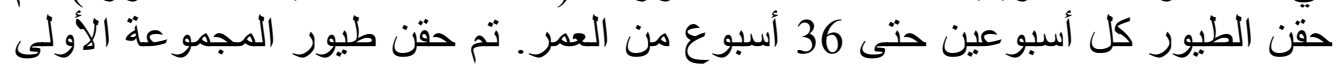


بمحلول ملحي9,. \% كنترول، وتم حقن الطيور في المعاملتين الثانية و الثالثة تحت الجلد

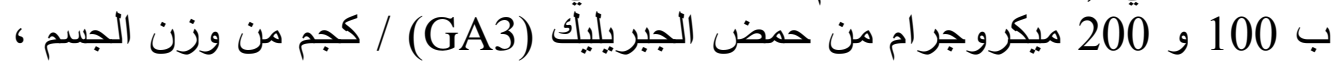

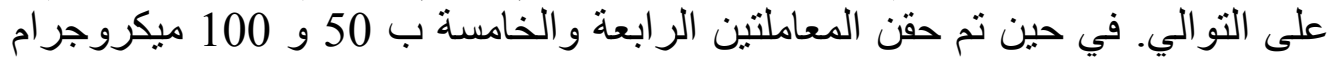

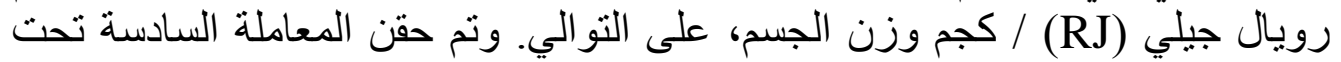

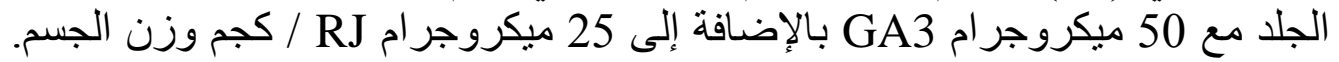
تم حقن المعاملة السابعة تحت الجلا مع الإم 100 ميكروجرام

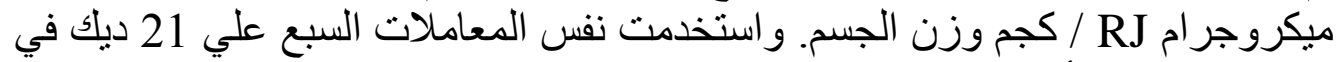
بطاريات فرديه لأخذ عينات جوده السائل المنوي.

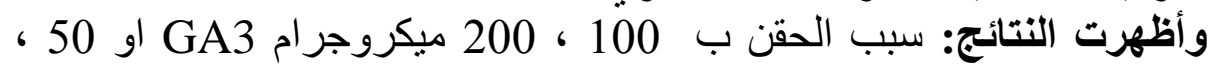
100 ميكروجر ام RJ / كجم من وزن جسم طيور مطروح في تحسن كبير (علي مستوي

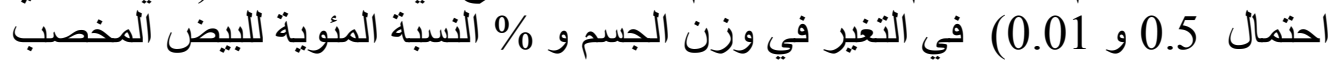

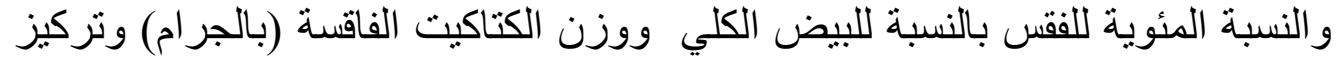

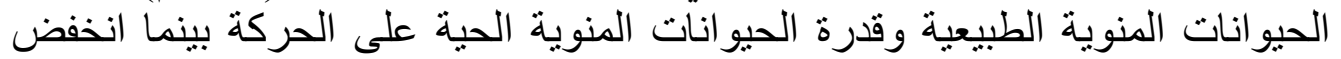

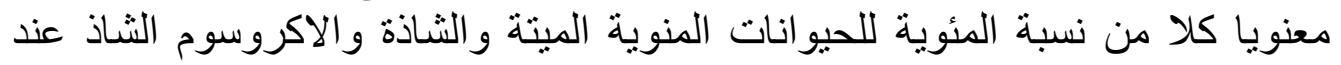

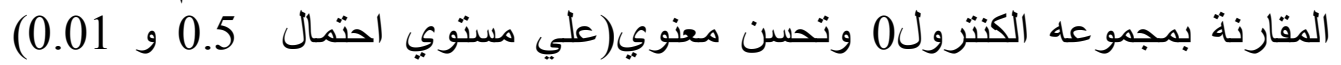

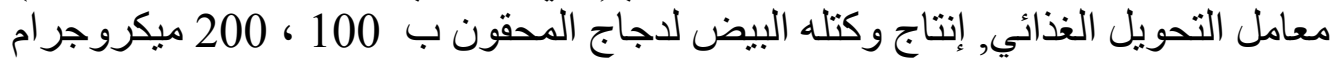

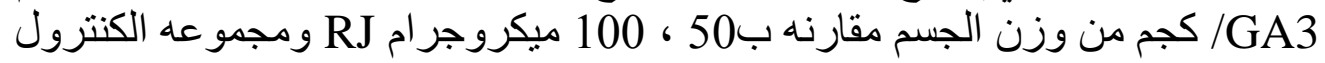

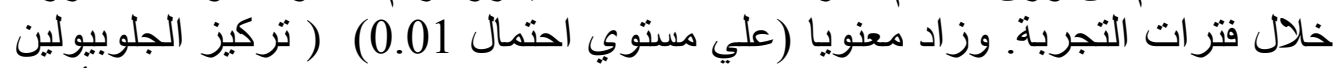

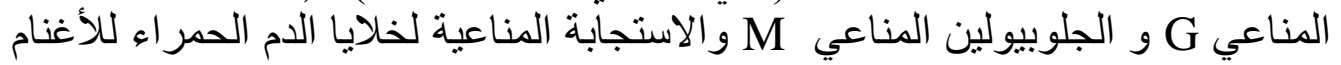

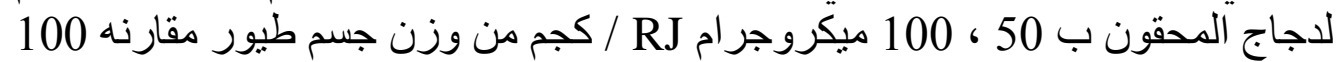

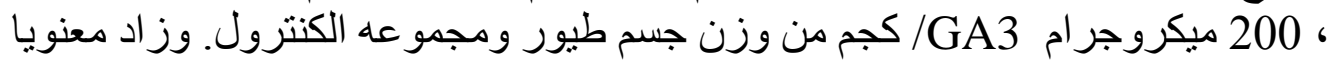

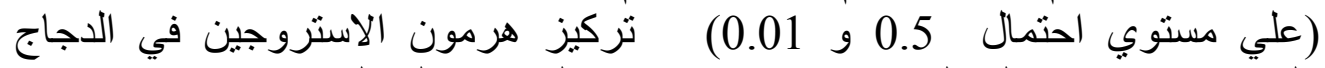
و التستوستيرون في الديوك ، FSH و LH في الدجاج و الديوك مقارنه مع مجمو عهد

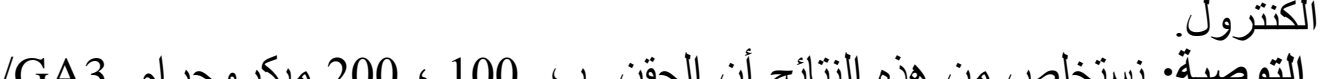

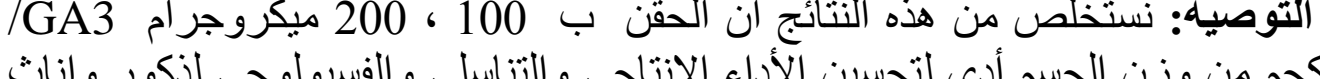

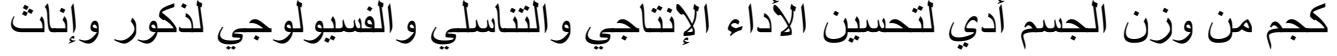

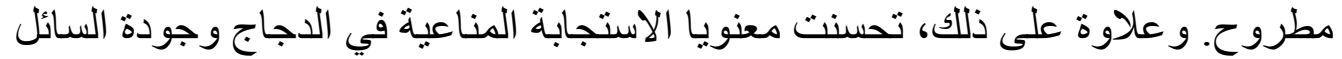

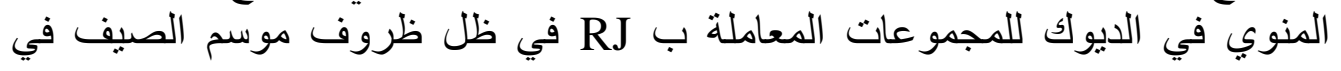

